\title{
Stability check of doubly fed induction generator (DFIG) micro grid power system
}

\author{
Ameerul A. J. Jeman' ${ }^{1}$, Naeem M. S. Hannoon ${ }^{2}$, Nabil Hidayat ${ }^{3}$, Mohamed. M. H. Adam ${ }^{4}$, Ismail \\ Musirin', Vijayakumar V.6 \\ 1,2,3,4,5 Faculty of Electrical Engineering, Universiti Teknologi MARA (UITM), Malaysia \\ ${ }^{6}$ School of Computing Science and Engineering, VIT University Chennai, India
}

\begin{tabular}{l}
\hline Article Info \\
\hline Article history: \\
Received Oct 18, 2018 \\
Revised Nov 22, 2018 \\
Accepted Feb 3, 2019 \\
\hline Keywords: \\
Doubly fed induction generator \\
Renewable energy \\
Stability \\
System reliability \\
Wind turbine
\end{tabular}

\begin{abstract}
As of late, expanding interest of renewable energy and consumption of nonrenewable energy source have prompted developing advancement of renewable energy technology, for example, wind energy. Wind energy has turned out to be one of the reliable sources of renewable energy, which requests extra transmission capacity and better methods for sustaining system reliability. As of now, doubly fed induction generator wind turbine is the most well-known wind turbine. This paper focuses on DFIG wind farm design using MATLAB/SIMULINK and also investigates the issues of the system stability of the DFIG wind turbine micro grid power system. This analysis includes the changes of voltage, current, real power and reactive power based on various conditions of the power system.
\end{abstract}

Copyright () 2019 Institute of Advanced Engineering and Science. All rights reserved.

\section{Corresponding Author:}

Naeem M. S. Hannoon,

Faculty of Electrical Engineering,

Universiti Teknologi MARA (UiTM),

40450 Shah Alam, Selangor, Malaysia.

Email: hannoon.naeem@gmail.com

\section{INTRODUCTION}

Microgrids are ending up progressively alluring to consumers and all things considered later on, an incredible number of them will be introduced at customer's locales since it has a huge potential in boosting the practical development. Microgrid frameworks, when suitably arranged, can separate and reconnect a distribution utility. Microgrids contrast from conventional electrical systems by strategies for giving an unrivaled closeness between power generation and power utilize, following in performance improvement and transmission decreasing. What's more, microgrids likewise coordinate with sustainable energy, for example, wind control, sunlight based, hydro, geothermal, and biomass. Renewable energy, particularly wind energy is enormously useful for ecological, climatic, financial conditions and in addition wellbeing. These days, increment in energy demand and decrease of fossil fuels have prompted the expansion of renewable energy $[1,2]$. Wind is ascending as a potential and a fundamental source of sustainable energy on account of its huge scale accessibility in diverse zones and in context of the focal points in regards to economy of power generation with wind on a huge scale $[3,4]$. The utilization of wind plants is increasing exponentially from the past. Wind power generation technology has gotten overall consideration and is relied upon to play out a huge part in the anticipated energy industry. Doubly-Fed Induction Generator (DFIG), at this time is the most popular wind generator due to its abundant advantages such as high efficiency, capability of providing reactive power support and relatively small rating of power converters [5]. The DFIG wind turbine, by definition, is a wound-rotor induction generator that functions either by governing the slip rings or by the power converter interconnected with grid [6]. A DFIG wind turbine is a complex setup including diverse physical spaces immovably coordinating with each other. The electrical structure, for example, is influenced 
by the converter's mechanical components and cooling system, together with the rotor blades, shaft and gearbox. This infers amid part selection and plan of control schemes the effect of areas on each other must be well-thoroughly measured in order to attain an overall system performance that the outline is dynamic, productive and cost effective [7].

Interconnection of microgrids is a useful method to accomplish higher usage of sustainable power source, diminish transmission losses, bring down infrastructure capital investment, and accomplish higher reliability of electricity supply. One of the sustainable sources, DFIG wind turbines have been utilized generally as of late. Aside from that, microgrid power system experiences astonishing quick changes regarding interest or generation arrays and trading actions that prevent the system operation and in addition security. At the point when wind turbines are created with huge power, a few issues emerge in associating it to control frameworks. This stability in the power system brings about the voltage and reactive power problem of the system. Voltage and reactive power control problems are substantial for nonstop case stability in power systems.

Correspondingly, it is basic to upgrade the stability in a microgrid, partaking a DFIG wind turbine so as to improve the power system performance. The stability of a system identifies with its reaction to inputs or disturbances. A system which stays in a constant state unless influenced by an external action and which remains to a steady state when the external action is evacuated can be considered to be stable. There is a requirement for stability analysis to decide how shut the system is to instability and to decide the steady-state performance and transient response. Special techniques are fundamental so as to avert instability without invading grid requirements [4].

This paper presents the stability check of doubly fed induction generator (DFIG) micro grid power system. In this study, a detail analysis was conducted on the dynamic behavior gained by a system. Simulations are conducted by developing the corresponding model in MATLAB/SIMULINK. The setting for stability analysis in a DFIG wind turbine based microgrid with various cases such as during islanding, fault during islanding with and without capacitive bank. Apart from that, simulation results illustrate the efficiency of the proposed method and objectives and its effect upon the stability of the microgrid. There are main objectives for this study, namely to analyze the effect on stability during certain conditions in microgrid power system, to design a microgrid consisting of a DFIG wind farm and to propose a strategy and system that improves the performance reliability in microgrid power system.

\section{MODEL DESCRIPTION OF DFIG SYSTEM}

\subsection{Doubly fed induction generator (DFIG) wind turbine}

DFIG can work in a higher wind speed range and yield or devour reactive power through the charge gave by the rotor-side converter, contrasting with conventional squirrel-cage induction generator wind turbine [8]. Basically, wind turbine driven on DFIG consists of Turbine and Drive Train, Wound Rotor Induction Generator, Wind Turbine Control, and AC-DC-AC Converter. By improving the turbine speed, DFIG permits separating most extreme vitality from the wind for low wind speeds, while restricting mechanical stresses on the turbine amid whirlwinds. The perfect turbine speed making most extreme mechanical vitality for a given breeze speed is relative to the breeze speed. In a commercial DFIG wind turbine, there are diverse kinds of energy storage components, for example, rotor mass of generator and dc-link capacitor of voltage source converter (VSC) for DFIG excitation [9].

\subsection{AC-DC-AC converter}

Whereas the wound rotor is fed from the Power Electronics Converter via slip rings to permit DFIG to function at a variability of speeds in response to altering wind speed, the stator is directly connected to the AC mains, Indisputably, the essential idea is to mediate a frequency converter between the variable frequency induction generator and fixed frequency grid. The DC capacitor linking stator-and rotor-side converters permits the capacity of energy from induction generator for further generation [10]. DC-link voltage must be enhanced to a level higher than the amplitude of grid line-to-line voltage with a specific end goal to accomplish full control of grid current.

\subsection{Turbine and drive train}

The power is transmitted from the rotor to the generator through the system comprising rotor shaft, shaft-hub clamping lock, multiplication gearbox, flexible coupling and other devices in typical wind turbine drivetrain [11]. 


\subsection{Wound rotor induction generator}

Regularly, the three phase generator rotor windings are associated with external resistors through a power electronic converter. Variation in the compelling rotor resistance will bring about a variation of the generator slip, which at last influences the rotational speed. The essential purpose behind utilizing a doubly-fed induction generator is for the most part to deliver three-stage voltage whose stator frequency is steady, for example, whose stator frequency stays equivalent to the system frequency of the ac power network to which the generator is associated, in spite of contrasts in the generator rotor speed instigated by varieties of the mechanical power gave by the prime mover (wind turbine rotor) driving the generator [12].

\subsection{Wind turbine control}

Wind Turbine Control can start and close down turbine operation alongside facilitates the operation of numerous wind turbines in response of operating and environmental conditions. [13] expressed that a controller is composed utilizing a sliding method of the terminal to diminish the system shifting by connecting the versatile modeling theory to manage the unspecified parameters and control signal smoothing with a specific end goal to enhance behavior of system outputs in the unstructured presence of vulnerabilities. The connected powerful examination and strong controller plan for an acceptance generator unit with a breeze turbine have been talked about [14]. To streamline wind turbine task some control plans, require a strategy for evaluating the breeze speed [15].

\section{RESEARCH METHOD}

In this study, the assessment of stability for wind energy driven doubly fed induction generator (DFIG) is conducted. The system focuses on how the voltage-current profile at load, real power at load and reactive power at load will be affected during:

a. Low Load (1MW)

1) During islanding without fault and without capacitive bank

2) During islanding without fault and with capacitive bank

3) During islanding with fault and without capacitive bank

4) During islanding with fault and with capacitive bank

b. High Load (100MW)

1) During islanding without fault and without capacitive bank

2) During islanding without fault and with capacitive bank

3) During islanding with fault and without capacitive bank

4) During islanding with fault and with capacitive bank

In this system, the power of wind turbine is $9 \mathrm{MW}$ consist of six $1.5 \mathrm{MW}$ connected to $25 \mathrm{kV}$ distribution system exports power to a $154 \mathrm{kV}$ grid through a $26.5 \mathrm{~km}, 25-\mathrm{kV}$ feeder in this system. This wind turbine system is included in the induction motor with power electronic IGBT converters.

\section{RESULTS AND ANALYSIS}

To harness the wind power efficiently the most reliable system in the present era is grid connected doubly fed induction generator (DFIG). Therefore, it is very crucial to know how the voltage-current profile, real power and reactive power of the overall power system in order to maintain the system stability. Apart from that, the comparison is done when capacitive bank is added to compensate the power quality of the system. Thus, through the collected result, the work is classified into various conditions of simulation. In each condition, the result of the simulations are compared in order to observe the differences.

Table 1 tabulates the results comparison of voltage-current profile during islanding for low load and high load. Four conditions have been considered in this study, namely (a) without fault and without capacitive bank, (b) without fault and with capacitive bank, (c) with fault and without capacitive bank and d) with fault and with capacitive bank. These results are presented in time domain for both the low load and high load. The load condition considers $1 \mathrm{MW}$, while the high load considers $100 \mathrm{MW}$. For each load condition, 2 responses are displayed to represent the voltage and current responses. The first waveform is the voltage response, while the second one is the current response.

From the table, the high load connected wind turbine experiences superior performance in both the voltage and current waveforms. This phenomenon happens to all the four conditions as can be observed in the table. In high load connected to wind turbine, the performance of the system is more stable with less fluctuations. For low load connected to the wind turbine, it is observed that all the 2 conditions without the capacitive bank exhibit oscillatory response in the beginning, followed by a long-time settlement. On the other hand, with the capacitive bank connected to the system; compensation process has been accommodated. 
This scheme has made the low load conditions settled down earlier as compared the condition without capacitive bank.

Table 1. Comparison of voltage-current profile during islanding for low load and high load

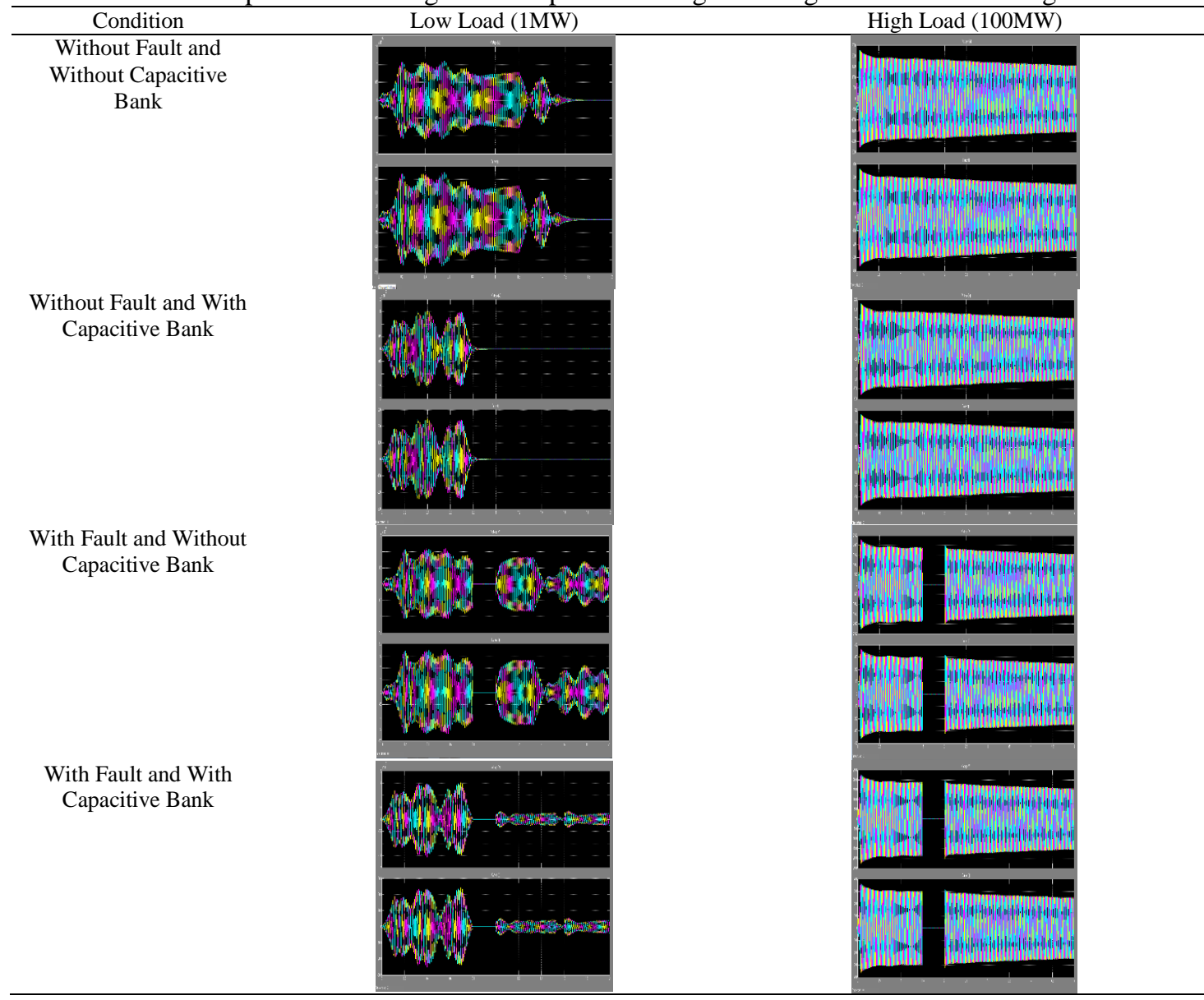

\subsection{Comparison data for low loading (1 MW) condition}

Table 2 tabulates the comparison result collected during islanding without fault and without capacitive bank. Six load conditions have been subjected to the system. The load is composite which combines the variations in active power and reactive power. The active power load is set constant worth 1 MW throughout the whole study, while the reactive power load varies from 10 VAR to 1MVAR as can be referred to the table.

Table 2. Comparison result collected during islanding without fault and without capacitive bank

\begin{tabular}{|c|c|c|c|c|}
\hline Load & Voltage (V) & Current (I) & Real Power $(\mathrm{W})$ & Reactive Power (VAR) \\
\hline $\begin{array}{c}\mathrm{P}=1 \mathrm{MW} \\
\mathrm{Q}=10 \mathrm{VAR}\end{array}$ & $17.03 \mathrm{k}$ & 27.24 & $10.62 \mathrm{M}$ & -104.7 \\
\hline $\begin{array}{c}\mathrm{P}=1 \mathrm{MW} \\
\mathrm{Q}=100 \mathrm{VAR}\end{array}$ & $17.03 \mathrm{k}$ & 27.25 & $10.62 \mathrm{M}$ & -1048 \\
\hline $\begin{array}{c}\mathrm{P}=1 \mathrm{MW} \\
\mathrm{Q}=1 \mathrm{kVAR}\end{array}$ & $17.09 \mathrm{k}$ & 27.35 & $10.68 \mathrm{M}$ & $-10.53 \mathrm{k}$ \\
\hline $\begin{array}{c}\mathrm{P}=1 \mathrm{MW} \\
\mathrm{Q}=10 \mathrm{kVAR}\end{array}$ & $18.42 \mathrm{k}$ & 29.46 & $11.16 \mathrm{M}$ & $110 \mathrm{k}$ \\
\hline $\begin{array}{c}\mathrm{P}=1 \mathrm{MW} \\
\mathrm{Q}=100 \mathrm{kVAR}\end{array}$ & $18.98 \mathrm{k}$ & 30.56 & $14.68 \mathrm{M}$ & $-1.436 \mathrm{M}$ \\
\hline $\begin{array}{c}\mathrm{P}=1 \mathrm{MW} \\
\mathrm{Q}=1 \mathrm{MVAR}\end{array}$ & $31.98 \mathrm{k}$ & 74.87 & $18.77 \mathrm{M}$ & $-17.78 \mathrm{M}$ \\
\hline
\end{tabular}


It is observed that, the increases from $17.03 \mathrm{kV}$ to its maximum value worth $31.98 \mathrm{kV}$ at the highest reactive power load. The same phenomenon occurs for current and real power. Nevertheless, the voltage and current increment do not happen at low VAR value, i.e. $10 \mathrm{VAR}$ and $100 \mathrm{VAR}$. Negative values of VAR as the output imply that reactive powers are absorbed by the system.

Table 3 tabulates the comparison result collected during islanding without fault and with capacitive bank. These are the results collected without fault, but capacitive bank was connected to the system. In general, the same load variations were subjected to the system. With the capacitive bank connected to the system, higher current and voltage values have been achieved as compared to the results in Table 2 . This implies that the presence of capacitive bank in the system has helped increased the voltage and current I the system. The same phenomenon is experienced by the real power and reactive power in the system.

Table 3. Comparison result collected during islanding without fault and with capacitive bank

\begin{tabular}{ccccc}
\hline Load & Voltage $(\mathrm{V})$ & Current (I) & Real Power (W) & Reactive Power (VAR) \\
\hline $\mathrm{P}=1 \mathrm{MW}$ & $149.2 \mathrm{k}$ & 238.6 & $53.39 \mathrm{M}$ & -501.3 \\
$\mathrm{Q}=10 \mathrm{VAR}$ & & & & -5336 \\
$\mathrm{P}=1 \mathrm{MW}$ & $33.14 \mathrm{k}$ & 53.02 & $56.76 \mathrm{M}$ & $-51.76 \mathrm{k}$ \\
$\mathrm{Q}=100 \mathrm{VAR}$ & & & & \\
$\mathrm{P}=1 \mathrm{MW}$ & $25.74 \mathrm{k}$ & 41.2 & $55.07 \mathrm{M}$ & $-652.3 \mathrm{k}$ \\
$\mathrm{Q}=1 \mathrm{kVAR}$ & & & & $-12.07 \mathrm{M}$ \\
$\begin{array}{c}\mathrm{P}=1 \mathrm{MW} \\
\mathrm{Q}=10 \mathrm{kVAR}\end{array}$ & $67.41 \mathrm{k}$ & 51.33 & $69.06 \mathrm{M}$ & $-135.9 \mathrm{M}$ \\
$\begin{array}{c}\mathrm{P}=1 \mathrm{MW} \\
\mathrm{Q}=100 \mathrm{kVAR}\end{array}$ & $84.76 \mathrm{k}$ & 136.4 & $124.1 \mathrm{M}$ & \\
$\begin{array}{c}\mathrm{P}=1 \mathrm{MW} \\
\mathrm{Q}=1 \mathrm{MVAR}\end{array}$ & $104.1 \mathrm{k}$ & 240.7 & $136.4 \mathrm{M}$ & \\
\hline
\end{tabular}

The comparison result collected during islanding with fault and without capacitive bank is tabulated in Table 4. Similar load variations as those in Table 2 and Table 3 are considered in this table. The voltage and current values are not consistent.

Table 4. Comparison result collected during islanding with fault and without capacitive bank

\begin{tabular}{|c|c|c|c|c|}
\hline Load & Voltage (V) & Current (I) & Real Power $(\mathrm{W})$ & Reactive Power (VAR) \\
\hline $\begin{array}{c}\mathrm{P}=1 \mathrm{MW} \\
\mathrm{Q}=10 \mathrm{VAR}\end{array}$ & $69.5 \mathrm{k}$ & 111.2 & $16.28 \mathrm{M}$ & -148.8 \\
\hline $\begin{array}{c}\mathrm{P}=1 \mathrm{MW} \\
\mathrm{Q}=100 \mathrm{VAR}\end{array}$ & $69.56 \mathrm{k}$ & 111.3 & $16.27 \mathrm{M}$ & -1488 \\
\hline $\begin{array}{c}\mathrm{P}=1 \mathrm{MW} \\
\mathrm{Q}=1 \mathrm{kVAR}\end{array}$ & $70.18 \mathrm{k}$ & 112.3 & $16.24 \mathrm{M}$ & $-14.85 \mathrm{k}$ \\
\hline $\begin{array}{c}\mathrm{P}=1 \mathrm{MW} \\
\mathrm{Q}=10 \mathrm{kVAR}\end{array}$ & $72.42 \mathrm{k}$ & 115.9 & $12.59 \mathrm{M}$ & $-120.6 \mathrm{k}$ \\
\hline $\begin{array}{c}\mathrm{P}=1 \mathrm{MW} \\
\mathrm{Q}=100 \mathrm{kVAR}\end{array}$ & $22.82 \mathrm{k}$ & 36.75 & $16.87 \mathrm{M}$ & $-1.543 \mathrm{M}$ \\
\hline $\begin{array}{c}\mathrm{P}=1 \mathrm{MW} \\
\mathrm{Q}=1 \mathrm{MVAR}\end{array}$ & $32.18 \mathrm{k}$ & 75.39 & $73.59 \mathrm{M}$ & $-69.42 \mathrm{M}$ \\
\hline
\end{tabular}

The same phenomenon also happens for both the real and reactive power values. The highest voltage and current values are experienced at $\mathrm{P}=1 \mathrm{MW}$ and $\mathrm{Q}=10 \mathrm{kVAR}$. The system also absorbs reactive power at all the load variations as can be observed from the same table.

Table 5 shows the results for voltage, current, real power and reactive power when the load is $1 \mathrm{MW}$ and Q from 10 VAR to 100 MVAR. This load variation is the same as those in all the previous cases, i.e. Table 1 to Table 4. For voltage and current, the results are decreasing until $1 \mathrm{kVAR}$ and increase back until 1 MVAR. Real power results do not have pattern. In general, the profiles of all the properties such as the voltage, current, real power and reactive power are not consistent. 
Table 5. Comparison result collected during islanding with fault and with capacitive bank

\begin{tabular}{|c|c|c|c|c|}
\hline Load & Voltage (V) & Current (I) & Real Power (W) & Reactive Power (VAR) \\
\hline $\begin{array}{c}\mathrm{P}=1 \mathrm{MW} \\
\mathrm{Q}=10 \mathrm{VAR}\end{array}$ & $34.63 \mathrm{k}$ & 55.4 & $53.39 \mathrm{M}$ & -501.3 \\
\hline $\begin{array}{c}\mathrm{P}=1 \mathrm{MW} \\
\mathrm{Q}=100 \mathrm{VAR}\end{array}$ & $108.9 \mathrm{k}$ & 174.2 & $56.76 \mathrm{M}$ & -5336 \\
\hline $\begin{array}{c}\mathrm{P}=1 \mathrm{MW} \\
\mathrm{Q}=1 \mathrm{kVAR}\end{array}$ & $34.35 \mathrm{k}$ & 54.97 & $55.07 \mathrm{M}$ & $51.76 \mathrm{k}$ \\
\hline $\begin{array}{c}\mathrm{P}=1 \mathrm{MW} \\
\mathrm{Q}=10 \mathrm{kVAR}\end{array}$ & $84.29 \mathrm{k}$ & 134.9 & $67.32 \mathrm{M}$ & $646.8 \mathrm{k}$ \\
\hline $\begin{array}{c}\mathrm{P}=1 \mathrm{MW} \\
\mathrm{Q}=100 \mathrm{kVAR}\end{array}$ & $42.93 \mathrm{k}$ & 82.65 & $124.1 \mathrm{M}$ & $-12.07 \mathrm{M}$ \\
\hline $\begin{array}{c}\mathrm{P}=1 \mathrm{MW} \\
\mathrm{Q}=1 \mathrm{MVAR}\end{array}$ & $129.3 \mathrm{k}$ & 302 & $148.3 \mathrm{M}$ & $-149.2 \mathrm{M}$ \\
\hline
\end{tabular}

\subsection{Comparison data for high loading (100 MW) condition}

The results for high loading conditions worth $100 \mathrm{MW}$ are tabulated in Tables 6, 7, 8 and 9. Table 6 tabulates the comparison result collected during islanding without fault and without capacitive bank. This table shows the results for voltage, current, real power and reactive power when the load is $1 \mathrm{MW}$ and Q from $10 \mathrm{VAR}$ to $100 \mathrm{MVAR}$. The voltage and current values are almost consistent for all the loading conditions. The same phenomenon also happens to the real power of the system. However, the reactive power values are not consistent for all the load values.

Table 6. Comparison result collected during islanding without fault and without capacitive bank

\begin{tabular}{|c|c|c|c|c|}
\hline Load & Voltage $(\mathrm{V})$ & Current (I) & Real Power (W) & Reactive Power (VAR) \\
\hline $\begin{array}{l}\mathrm{P}=100 \mathrm{MW} \\
\mathrm{Q}=10 \mathrm{VAR}\end{array}$ & 1834 & 293.5 & $807.6 \mathrm{k}$ & -0.0787 \\
\hline $\begin{array}{l}\mathrm{P}+100 \mathrm{MW} \\
\mathrm{Q}=100 \mathrm{VAR}\end{array}$ & 1834 & 293.5 & $807.6 \mathrm{k}$ & -0.787 \\
\hline $\begin{array}{l}\mathrm{P}=100 \mathrm{MW} \\
\mathrm{Q}=1 \mathrm{kVAR}\end{array}$ & 1834 & 293.5 & $807.6 \mathrm{k}$ & -7.87 \\
\hline $\begin{array}{l}\mathrm{P}=100 \mathrm{MW} \\
\mathrm{Q}=10 \mathrm{kVAR}\end{array}$ & 1834 & 293.5 & $807.7 \mathrm{k}$ & -78.7 \\
\hline $\begin{array}{c}\mathrm{P}=100 \mathrm{MW} \\
\mathrm{Q}=100 \mathrm{kVAR}\end{array}$ & 1835 & 293.5 & $807.7 \mathrm{k}$ & -787.1 \\
\hline $\begin{array}{l}\mathrm{P}=100 \mathrm{MW} \\
\mathrm{Q}=1 \mathrm{MVAR}\end{array}$ & 1835 & 293.7 & $808.6 \mathrm{k}$ & -7881 \\
\hline
\end{tabular}

The results for comparison during islanding without fault and with capacitive bank are tabulated in Table 7. Similar load variations are subjected to the system. From the table, the values for voltage, current and real power are consistent for all the load values. Apparently, the presence of capacitive bank has made the voltage, current and real power to be consistent due to the element of compensation process. However, the values for reactive power are not consistent due to different load values.

Table 7. Comparison result collected during islanding without fault and with capacitive bank

\begin{tabular}{|c|c|c|c|c|}
\hline Load & Voltage (V) & Current (I) & Real Power (W) & Reactive Power (VAR) \\
\hline $\begin{array}{l}\mathrm{P}=100 \mathrm{MW} \\
\mathrm{Q}=10 \mathrm{VAR}\end{array}$ & 1836 & 293.7 & $808.6 \mathrm{k}$ & -0.07882 \\
\hline $\begin{array}{l}\mathrm{P}=100 \mathrm{MW} \\
\mathrm{Q}=100 \mathrm{VAR}\end{array}$ & 1836 & 293.7 & $808.6 \mathrm{k}$ & -0.7882 \\
\hline $\begin{array}{l}\mathrm{P}=100 \mathrm{MW} \\
\mathrm{Q}=1 \mathrm{kVAR}\end{array}$ & 1836 & 293.7 & $808.6 \mathrm{k}$ & -7.882 \\
\hline $\begin{array}{l}\mathrm{P}=100 \mathrm{MW} \\
\mathrm{Q}=10 \mathrm{kVAR}\end{array}$ & 1836 & 293.7 & $808.6 \mathrm{k}$ & -78.82 \\
\hline $\begin{array}{c}\mathrm{P}=100 \mathrm{MW} \\
\mathrm{Q}=100 \mathrm{kVAR}\end{array}$ & 1836 & 293.7 & $808.7 \mathrm{k}$ & -788.2 \\
\hline $\begin{array}{l}\mathrm{P}=100 \mathrm{MW} \\
\mathrm{Q}=1 \mathrm{MVAR}\end{array}$ & 1836 & 293.8 & $809.4 \mathrm{k}$ & -7891 \\
\hline
\end{tabular}

The results for islanding case with fault and without the presence of capacitive bank are tabulated in Table 8. Similar load values were subjected to the system. Apparently, with fault occurrence in the system 
the voltage, current and real power of the system are consistent. Only the reactive power is not consistent. It implies that the fault occurrence has made the voltage, current and real power to be consistent.

Table 8. Comparison result collected during islanding with fault and without capacitive bank

\begin{tabular}{|c|c|c|c|c|}
\hline Load & Voltage (V) & Current (I) & Real Power $(\mathrm{W})$ & Reactive Power (VAR) \\
\hline $\begin{array}{l}\mathrm{P}=100 \mathrm{MW} \\
\mathrm{Q}=10 \mathrm{VAR}\end{array}$ & 1932 & 309.1 & $895.5 \mathrm{k}$ & -0.08931 \\
\hline $\begin{array}{l}\mathrm{P}+100 \mathrm{MW} \\
\mathrm{Q}=100 \mathrm{VAR}\end{array}$ & 1932 & 309.1 & $895.5 \mathrm{k}$ & -0.8931 \\
\hline $\begin{array}{l}\mathrm{P}=100 \mathrm{MW} \\
\mathrm{Q}=1 \mathrm{kVAR}\end{array}$ & 1932 & 309.1 & $895.5 \mathrm{k}$ & -8.931 \\
\hline $\begin{array}{l}\mathrm{P}=100 \mathrm{MW} \\
\mathrm{Q}=10 \mathrm{kVAR}\end{array}$ & 1932 & 309.1 & $895.5 \mathrm{k}$ & -89.32 \\
\hline $\begin{array}{c}\mathrm{P}=100 \mathrm{MW} \\
\mathrm{Q}=100 \mathrm{kVAR}\end{array}$ & 1932 & 309.1 & $895.8 \mathrm{k}$ & -894 \\
\hline $\begin{array}{l}\mathrm{P}=100 \mathrm{MW} \\
\mathrm{Q}=1 \mathrm{MVAR}\end{array}$ & 1935 & 309.7 & $898.6 \mathrm{k}$ & -9005 \\
\hline
\end{tabular}

Table 8 shows the results for voltage, current, real power and reactive power when the load is $1 \mathrm{MW}$ and Q from $10 \mathrm{VAR}$ to $100 \mathrm{MVAR}$. For voltage, current and real power, the results are increasing. It is different for reactive power. Results for reactive power vary for all the loads. The reactive power fluctuates when different reactive load value is gradually subjected to the system. Table 9 tabulates the comparison result collected during islanding with fault and with the presence of capacitive bank. Similar load values were subjected to the system. From the table, the values for voltage, current and real power are consistent for all load values subjected to the system. However, the reactive power of the system fluctuates with respect to the load variation. With the presence of capacitive bank in the system during fault for high loading condition, it does not give much impact to all the electrical properties. Comparison can be made between Table 8 and Table 9.

Table 9. Comparison result collected during islanding with fault and with capacitive bank

\begin{tabular}{|c|c|c|c|c|}
\hline Load & Voltage (V) & Current (I) & Real Power (W) & Reactive Power (VAR) \\
\hline $\begin{array}{l}\mathrm{P}=100 \mathrm{MW} \\
\mathrm{Q}=10 \mathrm{VAR}\end{array}$ & 1934 & 309.4 & $897.3 \mathrm{k}$ & -0.08945 \\
\hline $\begin{array}{l}\mathrm{P}=100 \mathrm{MW} \\
\mathrm{Q}=100 \mathrm{VAR}\end{array}$ & 1934 & 309.4 & $897.3 \mathrm{k}$ & -0.8945 \\
\hline $\begin{array}{l}\mathrm{P}=100 \mathrm{MW} \\
\mathrm{Q}=1 \mathrm{kVAR}\end{array}$ & 1934 & 309.4 & $897.3 \mathrm{k}$ & -8.945 \\
\hline $\begin{array}{l}\mathrm{P}=100 \mathrm{MW} \\
\mathrm{Q}=10 \mathrm{kVAR}\end{array}$ & 1934 & 309.4 & $897.3 \mathrm{k}$ & -89.46 \\
\hline $\begin{array}{c}\mathrm{P}=100 \mathrm{MW} \\
\mathrm{Q}=100 \mathrm{kVAR}\end{array}$ & 1934 & 309.4 & $897.5 \mathrm{k}$ & -895.5 \\
\hline $\begin{array}{l}\mathrm{P}=100 \mathrm{MW} \\
\mathrm{Q}=1 \mathrm{MVAR}\end{array}$ & 1936 & 309.9 & 900k & -9017 \\
\hline
\end{tabular}

Table 2 until Table 9 showed the comparisons between the presence and absence of fault and capacitive bank respectively. For high loading condition, the voltage-current profile, real power and reactive power are stable. The profiles do not show any major fluctuations and it can be seen that the system performance is reliable and better than the performance during low loading condition.

\section{CONCLUSION}

This paper has presented stability check of doubly fed induction generator (DFIG) micro grid power system. In this study, the modeling and stability assessment of doubly fed induction generator wind turbine micro grid power system has been proposed. A comparison of voltage-current profile, real power and reactive power of the load between low load and high load conditions has been studied. Voltage and current profile of the system are more stable with less fluctuation by adding capacitive bank compared to without capacitive bank. The analysis exhibits stable voltage and current profile when the capacitive bank is added to the grid. In overall conditions of the proposed model gave valuable understanding into the stability performance of the wind turbine equipped with a DFIG and the interaction between the wind farm and the main system. 


\section{ACKNOWLEDGEMENTS}

The authors would like to acknowledge the Institute of Research Management and Innovation (IRMI), Universiti Teknologi MARA, Malaysia for the financial support. This study was supported by IRMI under the LESTARI Research Grant Scheme under the Project Code: 600-IRMI/DANA 5/3/LESTARI (0169/2016).

\section{REFERENCES}

[1] R. L. Vasquez-Arnez, D. S. Ramos, and T. E. Del Carpio-Huayllas, "Microgrid dynamic response during the preplanned and forced islanding processes involving DFIG and synchronous generators," Int. J. Electr. Power Energy Syst., vol. 62, pp. 175-182, 2014.

[2] M. H. Ravanji and M. Parniani, "Stability Assessment of DFIG-Based Wind Turbines Equipped with Modified Virtual Inertial Controller under Variable Wind Speed Conditions," no. Iecon, pp. 2695-2700, 2017.

[3] T. Tamilarasi and M. K. Elango, "Analysis of impact on rotor angle stability of DFIG wind turbines employing STATCOM," ICACCS 2016 - 3rd Int. Conf. Adv. Comput. Commun. Syst. Bringing to Table, Futur. Technol. from Arround Globe, 2016.

[4] A. Mohanty, M. Viswavandya, P. K. Ray, and S. Patra, "Stability analysis and reactive power compensation issue in a microgrid with a DFIG based WECS," Int. J. Electr. Power Energy Syst., vol. 62, pp. 753-762, 2014.

[5] L. Wang and D. Truong, "Stability Enhancement of DFIG-Based Offshore Wind Farm Fed to a Multi-Machine System Using a STATCOM," in IEEE Transactions on Power Systems, vol. 28, no. 3, pp. 2882-2889, Aug. 2013.

[6] A. Pandey and K. A. Pandey, "Reactive Power Compensation for A Doubly Fed Induction Generator based WECS," Int. Conf. Innov. Information, Embed. Commun. Syst., 2017.

[7] M. Luo, "Multi-Physical Domain Modeling of a DFIG Wind Turbine System using PLECS ®," no. 2, pp. 1-13.

[8] B. Dong, S. Asgarpoor and W. Qiao, "Voltage analysis of distribution systems with DFIG wind turbines," 2009 IEEE Power Electronics and Machines in Wind Applications, Lincoln, NE, 2009, pp. 1-5.

[9] J. Hu, Y. Huang, D. Wang, H. Yuan and X. Yuan, "Modeling of Grid-Connected DFIG-Based Wind Turbines for DC-Link Voltage Stability Analysis," in IEEE Transactions on Sustainable Energy, vol. 6, no. 4, pp. 1325-1336, Oct. 2015.

[10] A. T. Submitted, I. N. Partial, F. Of, T. H. E. Requirements, O. F. The, and D. Of, "Study of Wind Turbine Driven Dfig Using Ac/Dc/Ac Converter a Thesis Submitted in Partial Fulfillment of," no. 10502049.

[11] R. Gawarkiewicz, F. Wasilczuk, and M. Wasilczuk, "Drivetrain of a Wind Turbine," Mach. Dyn. Res., vol. Vol. 39, N, no. June, pp. 83-95, 2015.

[12] S. F. Didactic, Electricity and New Energy Principles of Doubly-Fed Induction Generators (DFIG). 2011.

[13] S. M. Arbatsofla, A. Toloei, F. Soudagary and A. Naseri, "DFIG wind turbine control despite the uncertainties in the model using high-order adaptive sliding," 2017 Smart Grid Conference (SGC), Tehran, 2017, pp. 1-7.

[14] Alireza Khosravi, Ali Akbar Jalali, Ehsan Sarrami, "Applied Dynamic Analysis and Robust Controller Design of a Wind Turbine Generating Unit”, 19th International Power System Conference, Tehran, 2004.

[15] United States Patent 5289041, Speed control system for a variable speed wind turbine, Feb., 22, 1994. 